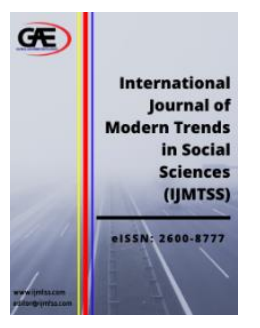

\author{
International Journal of Modern Trends in \\ Social Sciences (IJMTSS) \\ Journal Website: http://ijmtss.com/ \\ eISSN: $2600-8777$
}

\title{
THE IMPACT OF SALE PROMOTION ON IMPULSE BUYING BEHAVIOUR AMONG MUSLIM CREDIT CARD HOLDERS IN MALAYSIA
}

\author{
Siti Hajar Salwa Ahmad Musadik', Ilhaamie Abdul Ghani Azmi² \\ 1 Islamic Business School (IBS), Universiti Utara Malaysia (UUM), Malaysia \\ Email: ctsalwa@uum.edu.my \\ 2 Academy of Islamic Studies, Universiti Malaya (UM), Malaysia \\ Email: amieazmi@um.edu.my
}

\section{Article Info:}

\section{Article history:}

Received date:.24.12.2019

Revised date: 02.02.2020

Accepted date: 03.02.2020

Published date: 15.03.2020

\section{To cite this document:}

Musadik, S. H. S. A., \& Azmi, I. A. G. (2020). The Impact of Sale Promotion on Impulse Buying Behaviour among Muslim Credit Card Holders in Malaysia. International Journal of Modern Trends in Social Sciences, 3 (11), 34-49.

DOI: $10.35631 / I J M T S S .311003$.

\begin{abstract}
:
Studies pertaining to impulse buying have been substantially conducted in developing countries. Nevertheless, such studies are in scarcity amidst Asian countries, particularly Malaysia. Besides, studies that have looked into the variables of sale promotion is also rather sparsely carried out in the light of impulse buying behaviour. As such, this study examined the correlations between sale promotion on impulse buying behaviour among Muslim credit cardholders in Malaysia. In terms of instrument development, this study instrument adopted and adapted from prior studies. Questionnaires were distributed to 1,000 Muslim credit cardholders in Malaysia via purposive and snowball sampling techniques, wherein only 635 were usable for final data analysis. The analysis was performed via Partial Least Square (PLS-SEM) analysis. The outcomes revealed that sale promotion displayed significant positive correlations with impulse buying behaviour.
\end{abstract}

Keywords:

Impulse Buying Behaviour, Sale Promotion, Credit Card, Partial Least Square

\section{Introduction}

Buying activities is a part of the essential things in consumer life and in business management. Consumer perceived buying activities as part of life routine which are required to do, and the retailer perceives anything related to consumerism as essential for business development. Performing buying activities make consumer feel contented as they are able to fulfill their need and demand. While, knowing everything related to consumer behaviour facilitates the retailer in making their strategic marketing plans effectively and efficiently. Great marketing strategies capture the attention of potential consumers, which results to the intention to purchase or purchase impulsively. This situation can be seen every day, consumers do their purchasing Copyright (C) GLOBAL ACADEMIC EXCELLENCE (M) SDN BHD - All rights reserved 
activities as they are attracted to the ways retailers display and promote their goods and services. There are three forms of buying activities which are frequently conducted by consumers, namely; "Traditional Brick and Mortar" which are shopping activities in physical stores, "Internet Visual Shopping" where buyers make transactions via wireless communication such as online shopping, and the third form of shopping is done through "Virtual Connection" but the goods are picked at the physical store. Basically, consumer tend to practice impulse buying behaviour during offline shopping rather than online shopping (Aragoncillo and Orus, 2017) but other study found the presence of online shopping also stimulated consumers to practice impulse online shopping frequently as this method of shopping is very easy (Akram et al., 2017; Akram et al., 2018). This is demonstrated the different type of shopping channel does not bring any differences towards impulsive buyer. When they want something, they will pay for it although through online or offline channel.

In terms of factors that stimulate and trigger impulse buying behaviours, an overwhelming majority of previous researchers had already explored and investigated regarding it, such as (Chang, Yan, and Eckman, 2014; Kacen, Hess, and Walker, 2012; Zhuang et al. 2006; Tendai and Crispen, 2009; Mohan, Sivakumaran, and Sharma, 2013; Sharma, Sivakumaran, and Marshall, 2010b; Rook and Fisher, 1995; Huang, 2016). This impulsive buying is triggered by several internal and external factors such as time, location, economy, personality and the ease of purchase which is the main factor that creates impulsive buying among consumers. Ease of purchase is the feeling of pleasure from having enough money and time and the fact that the purchase process requires less physical and mental effort to make. When the consumer has sufficient money and time, experience less physical activity heading to a place of purchase and has a great schedule of flexibility for shopping at any store, thus, there is a higher likelihood that the consumer will practice impulsive buying (Stern, 1962). As reported by The Nielsen Global Survey of E-commerce (2014), the number of consumers in Malaysia making online shopping grew in the past two years and more than half of worldwide consumers shopped groceries online (The Nielsen Global Retail Format Preferences Survey, 2015). This demonstrates that the ease of shopping, price promotion, attractive advertisement encourages consumers to practice their shopping activities frequently and it is possible to claim that this situation stimulates the consumer to engage in impulsive buying (Liu et al., 2013).

As reported by Jabatan Insolvensi Malaysia (2017), credit card debt as one of the factors contribute towards financial problem among Malaysian and 55.31\% was Muslim group. This statistic demonstrated that, there are some of Muslim who still unable to manage their financial effectively particularly during sale promotion period. This is proven by previous study finding on impulse buying behaviour by Akram et al., (2018) which is found sale promotion as one of vital factor to enhance impulsive buying as consumer tend to make a spontaneous purchase during promotion period. They are also found the factor of credit card as one of the main key that stimulate consumer to practice impulsive buying Therefore, the vital problem that the researcher of this study wants to explore is pertaining to the impulse buying behaviour among Muslim credit card holder in Malaysia by examine whether sale promotion variable have a significant positive relationship with impulse buying behaviour in the context of Muslim credit card holders.

Previous studies were inclined to conduct their studies among university and college students (Beatty and Elizabeth Ferrell, 1998; Rook and Fisher, 1995; Youn and Faber, 2000; Luo, 2005; Sultan, Duarte, Raposo, and Ferraz, 2013; Burgess, Yaoyuneyong, and Gibbs, 2014; Thompson and Prendergast, 2015; Chuang, Tian, and Lin, 2015; Lucas and Koff, 2017; Seinauskiene, Mascinskiene, \& Jucaityte, 2015; Sofi \& Nika, 2017) and non-specific consumers (Ek Styven, 
Foster, \& Wallstrom, 2017; Badgaiyan, Verma, \& Dixit, 2016; Badgaiyan, Dixit, \& Verma, 2017; Bahrainizad \& Rajabi, 2018; Turkyilmaz, Erdem, \& Uslu, 2015; Akram et al., 2018; Wu and Lee, 2015; Ozer and Gultekin, 2015; Badgaiyan and Verma, 2015; Hulten and Vanyushyn, 2011; Chang, Yan, and Eckman, 2014). However, limited attention has been focused towards impulse buying behaviour among specific groups of consumers such as credit card holders and Muslim group. As Muslims form a sizeable proportion of consumers globally, examining and exploring how Muslim consumers react with impulse buying behaviour will contribute towards the body of knowledge in this field. To date, there has been scarce previous study focus on the impact of sale promotion factor in practice of impulsive buying particularly in Malaysia context. Clearly, the requirement for more study effort is justified.

\section{Proposed Hypotheses and Model}

\section{Chronology and Definition of Impulse Buying Behaviour}

The definition of impulsive buying behaviour by researchers and academics varies, especially within the marketing sector where the term and meaning invariably changes. Research into impulse buying began in the early 1950s resulting from the advent of the retail industry. During this period, Du Pont conducted a series of studies on impulse buying behaviour, notably, Consumer Buying Habits Studies (1948-1965) sponsored by the Point of Advertising Institute. The studies concluded that impulse buying behaviour is defined as unplanned buying and these studies further created an impulse buying behaviour model that was used for much of the earlier research (Rook, 1987). Subsequently, numerous studies examined the influence and regularity of customer impulse buying behaviour in various forms including; sales patterns (Clover, 1950), food and cosmetics (West, 1951), as well as the consumer types and buying patterns (Applebaum, 1951). Further, extensive studies were undertaken by researchers such as (Stern, 1962) on impulse buying behaviour to understand further the different types of buying and the different range of products that could be classified into two distinct categories which are impulse and non-impulse products. Usually, within the context of marketing, impulse buying does not explicitly refer to any specific type of product and service, except for buying decisions related to food (Kollat and Willett, 1969).

Many previous studies were mainly conducted in western countries, for instance, the USA (Lucas and Koff, 2017; Lins et al. 2015; Bossuyt et al. 2017; Cengiz 2017), and Sweden (Hulten and Vanyushyn, 2014; Hulten and Vanyushyn, 2011). Also in the United Kingdom (Floh and Madlberger, 2013), South Africa (Tendai and Crispen, 2009), France (Muratore, 2016), Ireland (Dhaundiyal and Coughlan, 2016), the Netherlands (Verhagen and Van Dolen, 2011), Turkey (Ozen and Engizek, 2014; Ozer and Gultekin, 2015). Also in Asian countries such as India (Prashar, Parsad, and Vijay, 2016; Badgaiyan and Verma, 2015; Atulkar \& Kesari, 2018), China (Chuang, Tian, and Lin, 2015; Chen and Wang, 2015), Thailand (Burgess, Yaoyuneyong, and Gibbs, 2014), Indonesia (Tjiptodjojo and Setyawan, 2016), Singapore (Pornpitakpan, Yuan, and Han, 2016), and Malaysia (Khan et al. 2015; Falahat et al. 2017; Mokhlis, 2009b; Leong, Jaafar, \& Sulaiman, 2017).

In the Malaysian context, the previous studies by Falahat et al. (2017) and Khan et al. (2015) discussed impulse buying behaviour in the apparel and footwear context among the Generation $\mathrm{Y}$ and female shoppers. In a study by Mokhlis (2009b), he explained more on buying behaviour and not wholly on impulse buying behaviour. Prior studies on impulse buying behaviour in Malaysia tended to investigate the subject in a more general context, i.e. within the scope of conventional consumerism. It is also difficult to locate studies that examine and discuss impulse buying behaviour from the perspective of religion. Previous researchers have tended 
to explain impulse buying behaviour regarding both consumerism and psychology, which are typically related to human actions, feelings, and the situation. Therefore, significant gaps need to be filled or closed through undertaking future studies. In this regard, this study attempts to fill this gap through exploring impulse buying behaviour among Muslim credit card holders in Malaysia by investigating the relationship between sale promotion and impulse buying behaviour which will undoubtedly extend the body of knowledge in this area.

\section{Sale Promotion}

In the marketing domain, promotion in any shape or form is seen as a strategic and vital tool to facilitate the marketer in supporting the business to achieve its goals (Alvarez and Casielles, 2005). In consumer retailing, marketers will aim to attract consumers using a variety of sales tactics and promotions such as by offering coupons, membership cards, member card days, personalised shopping, an attractive and friendly store environment, and providing charming and persuasive shop assistants (Tendai and Crispen, 2009). Promotions in most cases, if performed correctly, will increase the propensity to purchase among consumers (Cotton and Babb, 1978). Importantly, promotions are essential in retailing operations to sustain the business, attract new customers while retaining existing customers and to gain a competitive advantage over other retail companies. For operational definition of this sale promotion variable, this study defines sales promotion as offering incentives to consumers to pay for products and services which usually fall within the scope of the marketing and communications function and plan of an organisation. This variable is measured according to the nature of the promotion; price discount, extra products, free gifts, and membership discount days, and so forth (Stone and Desmond, 2007).

Previous studies in buying behaviour have explored the function of sales promotion upon buying behaviour pattern and in the retailing industry by suggesting that promotional activities will often result in positive effects, such as offering free samples which may lead to an immediate purchase (Lammers, 1991). Frequently, a sales promotions will help the consumer towards deciding which brand to purchase (Alvarez and Casielles, 2005). Sales promotions typically form part of the marketing communication plan within a business that offers customer incentives to purchase products and services (Alvarez and Casielles, 2005; Peattie and Peattie, 1995). Furthermore, the retailer will develop sales promotion campaigns, often to realise immediate profits through discounting prices, offering extra products, free gifts, as well as promoting membership discount days, which inevitably captures the consumers desire to spend money (Stone and Desmond, 2007).

On the other hand, regarding sales promotion preferences, Weng and Run (2013) and Pelet et al (2018) indicated that the techniques associated with sales promotion will influence consumer buying behaviours, such as price promotion having a much higher influence on consumer buying behaviour than other promotional methods (Alvarez and Casielles, 2005) and percentage price presentation being utilised when substantial discounts are offered. For small promotions, bonus packs are typically offered as part of the promotion campaign (Hardesty and Bearden, 2003). Also, regarding price discounts, presentation, and consumer attraction to the structure of the promotions, consumers reported that price discount more attracted rather than gift giving (Gong, Hou, Zhang, \& Tian, 2018) and price discount presentations in dollar terms influence and stimulate them to purchase expensive products rather than price discount presentations displayed in percentage terms (Chen, Monroe, and Lou, 1998).

Consumers further tend to practice high impulse buying when an inexpensive product has a price discount, and an expensive product promotion offers a bonus pack (Xu and Huang, 2014). 
Therefore, it can be concluded that a sales promotion has a positive relationship with impulse buying behaviour. Evidently, it has also been proven how consumers perceive the element of price during sales promotion activities. For example, low price consumers will perceive price as the amount of money that must be sacrificed, and a higher price will result in an adverse effect on purchases. High price consumers use price cues as indicators in evaluating product quality, and higher prices will positively influence purchase probabilities (Lichtenstein, Ridgway, and Netemeyer, 1993). According to this statement, there is a distinct possibility that consumers will frequently practice impulse buying behaviour when they experience a sales price promotion situation or moment. This finding is also in parallel with the conclusion by Liao, Shen, and Chu (2009) stating that strong reminder impulse buying consumers tend to be influenced by instant reward promotions rather than delayed rewards. Further, they will also purchase both utilitarian and hedonic goods during sales promotion periods and prefer to be attracted by price promotional sales rather than another type of sales promotion. The category of goods whether utilitarian or hedonic is frequently ignored during sales promotion periods as consumers tend to make purchases without prior consideration to obtain the advantage of sales promotions (Martinez and Montaner, 2006). This evidence demonstrates that there is possibility that consumers will practice impulse buying behaviour to capture the opportunity during a sales promotion.

The correlation between sales promotion and impulse buying behaviour from previous studies suggested that sales promotions have a significant positive relationship with impulse buying behaviour (Akram et al., 2018; Badgaiyan and Verma, 2015; Kacen, Hess, and Walker, 2012; Chen and Wang, 2015). For instance, concerning a product category sales promotion, a study by Xu and Huang (2014) revealed that price discounts on hedonic products influence a greater impulse buying intention as compared to bonus gift packs. Instead, gift packs are useful for utilitarian products, where price reduction profoundly influences impulsive buying rather than price discounts (Chen and Wang, 2015). Also, for product pricing, consumers tend to practice impulsive buying when bonus pack promotions are offered for expensive products, and price discounts are offered for less expensive products. This statement is in parallel with the prior study by Tinne (2011), that was conducted in Bangladesh. The study indicates that a pricing strategy is more likely to influence consumers to practice impulse buying, and a high-low pricing strategy will effectively influence consumer impulse buying behaviour in product and retail buying (Kacen, Hess, and Walker, 2012).

Also, a recent study suggested that sales promotion is the primary factor influencing online Internet impulse buying (Akram et al., 2018; Lo, Lin, and Hsu, 2016). Akram et al., (2018) through their study state that website sale promotion strategy influence credit card holders to buy impulsively via online shopping. Meanwhile, in terms of scope, many of the previous studies examined the correlation between sales promotion and impulse buying behaviour conducted among consumers and college students in western countries such as the United State (Kacen, Hess, and Walker, 2012), and Asian countries such as India (Badgaiyan and Verma, 2015) and Taiwan (Chen and Wang, 2015; Lo, Lin, and Hsu, 2016). In Malaysia, there have been only a few studies undertaken on sales promotion and impulse buying behaviour. Therefore, this study attempts to close this gap by exploring and examining the correlation between sales promotion and impulse buying behaviour in a different scope of the study, which is among Muslim credit card holders in Malaysia. This exploration involves a different location and a group of respondents which will contribute additional knowledge in the study of impulse buying behaviour. Thus, this study believes that sales promotion has positive effects that stimulate consumers to practice impulsive buying. Accordingly, this study proposes the 
following hypothesis:H1: There is a significant positive relationship between sales promotion and impulse buying behaviour.

\section{Research Methodology}

\section{Participants and Procedure}

Data for this study were collected among Muslim credit card holders in Malaysia. As the data in this study is regarded as nonprobability sampling, the data collection activities were undertaken via purposive sampling and by snowball sampling using two techniques; the contact network and through self-assessment (Bryman and Bell, 2007; Rowley, 2014). The contact network method included family, friends, work colleagues, relatives and acquaintances. Following the distribution of the 1,000 questionnaires used to survey Muslim credit card holders in Malaysia, 710 were ultimately returned. After reviewing the returned questionnaires, 635 were determined to be usable for the data analysis in the study.

\section{Development and Instrument}

In this study's questionnaire, there are two main sections that need to be answered by the potential respondents. Section A covers impulse buying behaviour, sales promotion and section B contains some information about the respondent's background. There are nine items of questions in this section A that evaluate impulse buying behaviour among credit card holders. The questions are about the elements of spontaneity and urge to purchase, which reflect impulsive buying behaviour. Next, the independent which are related to the situational variable, namely; sales promotion were adopted and adapted from (Karbasivar and Yarahmadi, 2011). All of these questions used the Likert scale as the measurement scale.

\section{Statistical Technique}

This study employed the Structural Equation Model (SEM) analysis technique via Partial Least Squares (PLS) in order to meet the objective of this study. In addition, exploratory factor analysis for testing the selected items of the questionnaire and descriptive analysis for the general angle of respondents were also applied in this study. For statistical tools, this study was analysed and run through Partial Least Squares (PLS) technique. This method functions to increase the variance of the dependent variable demonstrated by the independent variable instead of recreating the empirical covariance matrix. The principal idea of PLS is quite uncomplicated, which involves estimation of the weight relations, calculation of case values of unobservable variables, and using the case values in a set of regression equation to ascertain the parameter for the structural relations. One of the outstanding benefits of PLS-SEM is that this method is able to control and handle non-normal data and complex models with a large number of constructs ( Hair et al. 2017).

\section{Data Analysis}

Two models are measured in the PLS-SEM analysis; the measurement model and the structural model. The assessment of measurement model includes two analyses namely; convergent validity and discriminant validity. While, in the structural model, the estimation comprises the coefficient of determination $\left(\mathrm{R}^{2}\right)$, predictive relevance $\left(\mathrm{Q}^{2}\right)$, size and significance of path coefficients, $\mathrm{f}^{2}$ effect size, and $\mathrm{q}^{2}$ effect size. Result below demonstrated the descriptive analysis, measurement model, and structure model analysis.

\section{Descriptive Analysis}

The descriptive analysis, Table 1 illustrate the profile of the 635 Muslim credit card holders in this study applying five categories; gender, age, income, education and type of credit card. Of 
all the respondents, females represented 60.8 percent $(n=386)$ of the sample population, while males represented 39.2 percent $(n=249)$, while $47.1 \%(n=299)$ of the respondents age at 31 41years old, followed by $27.2 \%(n=173)$ at age $42-50$ years old and the rest $15.4 \%(n=98)$ at 22-30 years old and $10.2 \%(n=65)$ 51-65 years old respectively. Meanwhile, the income of Muslim credit card holders demonstrated that most earn an income ranging between RM3,001 to RM6,000, representing 46.9 percent $(n=295)$. While, 29.0 percent $(n=184)$ reported earning income ranging between RM 6,001 to RM 9,000, followed by 15.0 percent $(n=95)$ with income between RM 2,000 to RM 3,000, and finally, 9.1 percent $(n=58)$ earning income of RM 9,000 or higher. In terms of the respondents' educational background, the most are Master holders at 40.9 percent $(n=260)$, followed by 26.5 percent $(n=168)$ and 16.5 percent (105) of those who hold a Degree or are a Doctor of Philosophy holder, respectively. Next, 11.8 percent $(n=75)$ were represented as graduates with a diploma/certificate level of study, and lastly, secondary school holders representing the minority group at 4.3 percent $(n=27)$. Finally, in terms of type of credit card possessed by the respondents, the most of respondents used an Islamic credit card at 52.0 percent $(n=330)$. The remaining used a conventional credit card, and an Islamic credit card either individually or had both, demonstrated a slight difference at 29.3 percent $(n=186)$ to those who used a conventional credit card and 18.7 percent $(n=$ 119) using both an Islamic credit card as well as a conventional credit card.

Table 1: Respondents Demographic Characteristic

\begin{tabular}{|l|l|l|}
\hline Construct & Frequency & Percentage \\
\hline Gender & & \\
Male & 249 & $39.2 \%$ \\
Female & 386 & $60.8 \%$ \\
\hline Age & & \\
22 to 30 & 98 & $15.4 \%$ \\
31 to 41 & 299 & $47.1 \%$ \\
42 to 50 & 173 & $27.2 \%$ \\
51 to 65 & 65 & $10.2 \%$ \\
\hline Income & & \\
RM 2,000-RM 3,000 & 95 & $15.0 \%$ \\
RM 3,001-RM 6,000 & 298 & $46.9 \%$ \\
RM 6,001-RM 9,000 & 184 & $29.0 \%$ \\
RM 9,001 and above & 58 & $9.1 \%$ \\
& & \\
\hline Education & & \\
Secondary School & 27 & $4.3 \%$ \\
Diploma/Certificate & 75 & $11.8 \%$ \\
Degree & 168 & $26.5 \%$ \\
Master & 260 & $40.9 \%$ \\
Doctor of Philosophy & 105 & $16.5 \%$ \\
\hline Type of credit card & & \\
Islamic Credit Card & 330 & $52.0 \%$ \\
Conventional Credit Card & 186 & $29.3 \%$ \\
Islamic and Conventional Credit & 119 & $18.7 \%$ \\
Card & & \\
\hline
\end{tabular}




\section{Measurement Model}

The measurement model (PLS Algorithm) includes two analyses; convergent validity and discriminant validity. Convergent validity incorporates three additional analyses namely; Outer Loading Analysis, Average Variance Extracted (AVE) and Composite Reliability (CR) function to measure the extent to which a measured item correlates with other items in the same construct (Hair, Hult, Ringle, \& Sarstedt, 2017). The discriminant validity assessment also performs three analyses, namely; Fornell-Larcker Criterion, Cross Loading, and HeterotraitMonotrait Ratio (HTMT).

Construct validity is assessed by estimating the cross loading and outer loading. Further, the outer loading is conducted to identify the items that have high and low loading. Accordingly, the low loading needs to remove, and the high outer loading determines how much the indicator has in common. A standard rule of thumb for standardising outer loading should be 0.708 or higher (Chin, Gopal, Salisbury, \& David, 1997; Hair et al., 2017). However, in social science studies, researchers frequently obtain a weaker outer loading lower than 0.70 mainly when related to newly developed scales (Hulland, 1999). Table 2 demonstrated the remaining items loading from the model assessment and the values of average variance extracted (AVE), composite reliability, and Cronbach's alpha.

Table 2: Average Variance Extracted (Ave), Composite Reliability, And Cronbach's Alpha Assessment

\begin{tabular}{|l|l|l|c|c|c|}
\hline Construct & Items & Loading & $\begin{array}{l}\text { Average Variance } \\
\text { Extracted (AVE) }\end{array}$ & $\begin{array}{l}\text { Composite } \\
\text { Reliability }\end{array}$ & $\begin{array}{l}\text { Cronbach's } \\
\text { Alpha }\end{array}$ \\
\hline $\begin{array}{l}\text { Impulse Buying } \\
\text { Behaviour }\end{array}$ & IBBQ1 & 0.792 & 0.569 & 0.887 & 0.847 \\
\hline & IBBQ2 & 0.839 & & & \\
\hline & IBBQ3 & 0.708 & & & \\
\hline & IBBQ4 & 0.764 & & & \\
\hline & IBBQ5 & 0.710 & & & \\
\hline & IBBQ6 & 0.704 & & & 0.863 \\
\hline Sale Promotion & SPQ1 & 0.738 & 0.648 & & \\
\hline & SPQ2 & 0.788 & & & \\
\hline & SPQ3 & 0.765 & & & \\
\hline & SPQ4 & 0.863 & & & \\
\hline & SPQ5 & 0.863 & & & \\
\hline
\end{tabular}

Sources: Developed for This Study

The purpose of discriminant validity is to identify the extent to which a given construct is distinct from other constructs. To establish discriminant validity on the Fornell-Larcker criterion, the square root of each construct's AVE should be higher than its correlation with other constructs (Hair et al., 2017). According to Table 3 the result of using Fornell-Larcker criterion demonstrated that the discriminant validity had been established in this study by obtaining higher values of square roots of each construct AVE namely, impulse buying behaviour (0.754) and sale promotion (0.805). 


\begin{tabular}{|l|l|l|}
\hline & \multicolumn{1}{|c|}{$\begin{array}{c}\text { Impulse Buying } \\
\text { Behaviour }\end{array}$} & Sale Promotion \\
\hline Impulse Buying Behavior & 0.754 & 0.805 \\
\hline Sale Promotion & 0.542 & \\
\hline
\end{tabular}

Table 3: Fornell-Larcker Criterion Assessment

Sources: Developed for This Study

Finally, as a further alternative in assessing discriminant validity issues in this study, the Heterotrait-Monotrait Ratio (HTMT) was applied as suggested by (Henseler, Ringle, and Sarstedt 2015). By using 0.85 (Henseler, Ringle, and Sarstedt, 2015) and 0.90 (Henseler, Ringle, and Sarstedt, 2015) as the threshold value for HTMT, this analysis indicated that all HTMT values are obviously lower than the threshold values of HTMT, namely; 0.85 and 0.90 . This suggested, therefore that adequate discriminant validity of this study was established.

Table 4: Heterotrait- Monotrait Ration (Htmt) Assessment

\begin{tabular}{|l|l|l|}
\hline & $\begin{array}{c}\text { Impulse Buying } \\
\text { Behaviour }\end{array}$ & Sale Promotion \\
\hline IBB & & \\
\hline SP & 0.632 & \\
\hline
\end{tabular}

Sources: Developed for This Study

\section{Structural Model}

The structural model functions to demonstrate the causal relationship between the constructs in the model. This includes the estimates of the path coefficient, which indicated the relationship between the exogenous variables, endogenous variable, and the $\mathrm{R}^{2}$ value, which demonstrated the numbers of variance explained by the exogenous variables, the effect size $\left(\mathrm{f}^{2}\right)$ and the predictive relevance $\left(\mathrm{Q}^{2}\right)$ assessment.

Table 5: Hypotheses Test (Direct Relationship)

\begin{tabular}{|c|c|c|c|c|c|}
\hline $\begin{array}{c}\text { Hypothesis \& } \\
\text { Path }\end{array}$ & Beta Values & $\begin{array}{c}\text { Standard } \\
\text { Error }\end{array}$ & T Values & $\begin{array}{c}\text { P } \\
\text { Values }\end{array}$ & $\begin{array}{c}\text { Significance } \\
\text { Level }\end{array}$ \\
\hline H1: SP $\rightarrow$ IBB & 0.227 & 0.044 & $5.159 * * *$ & 0.000 & Significant \\
\hline
\end{tabular}

Sources: Developed for This Study

Table 5 displays the results of the structural model analysis of a direct relationship between the independent variables of sale promotion and the dependent variable of impulse buying behaviour in this study. Following the structural model analysis procedure, collinearity issues were checked by examining the VIF values of all sets of predictor constructs. The results demonstrated that all VIF values are clearly below the threshold of 5 which indicated that collinearity among the predictor constructs is not a critical issue in a structural model (Hair, Ringle, \& Sarstedt, 2011). Following the collinearity procedure, the researcher carried out a bootstrapping analysis to test the significant relationship between the exogenous variables and the endogenous variable. According to Table 5, the bootstrapping one-tailed analysis using 5000 samples was undertaken with the result indicating that all the independent variables sale 
promotion have a significant relationship with the dependent variable, impulse buying behaviour. To identify the significant level of the one-tailed tests, the $t$ values are required to be higher than the three levels of critical values; 1.28 (significant level $=10 \%$ ), 1.65 (significant level $=5 \%$ ), and 2.33 (significant level $=1 \%$ ) (Hair et al., 2017). The results, therefore, indicated the following:

H1: There is a significant positive relationship between sale promotion and impulse buying behaviour. For this hypothesis, the result found that there is a significant positive relationship between sale promotion and impulse buying behaviour $(\beta=0.227, \mathrm{t}=5.159, \mathrm{p}<0.01)$ and therefore, this hypothesis is supported.

Table 6: Assessment of Coefficient of Determination $\left(R^{2}\right)$, The Effect Size $\left(F^{2}\right)$ And The Predictive Relevance $\left(Q^{2}\right)$ Of Direct Relationship.

\begin{tabular}{|l|l|l|l|}
\hline \multicolumn{1}{|c|}{ Construct } & \multicolumn{1}{c|}{ F Square } & \multicolumn{1}{c|}{ R Square } & Q Square \\
\hline $\mathrm{SP} \rightarrow \mathrm{IBB}$ & 0.051 & & \\
\hline $\mathrm{IBB}$ & & 0.427 & 0.225 \\
\hline
\end{tabular}

Sources: Developed for This Study

As depicted in Table $6, \mathrm{R}^{2}$ of this analysis is considered moderate with a coefficient value at 0.427. Meanwhile, referring to (Cohen et al. 2003), in the guideline to assess the effect size of $\mathrm{R}^{2}$, there are three levels of effect sizes which are measured by large $(0.26)$, medium $(0.13)$, and small (0.02) effect size. Therefore, according to the result above, the $f$ square $\left(\mathrm{f}^{2}\right)$ result shows that all the independent variables have an impact on the dependent variable but with notable small effect size, and with values ranging from 0.003 to 0.093 . While, for the predictive relevance $\left(\mathrm{Q}^{2}\right)$, the results show the path model has the predictive relevance of the dependent variable by $\mathrm{Q}^{2}$ value at 0.225 which is higher than zero.

\section{Discussion}

The PLS-SEM analysis result indicated significant evidence towards the relationship between the independent variable, sale promotion and the dependent variable, impulse buying behaviour. Sale promotion found to be positive and significantly related to impulse buying behaviour.

The results of this study provide further evidence that the factor of sales promotion has a significant relationship with impulse buying behaviour among Muslim credit card holders in Malaysia. This result is in parallel with previous studies (Badgaiyan and Verma, 2015; Hulten and Vanyushyn, 2014), who also suggest that the sales promotion factor is one of the signals that trigger consumers to practice impulse buying. Previous research has also confirmed this fact. For example, in a study by Neslin, Henderson, and Quelch (1985), one of the potential consequences of sales promotion is accelerated buying resulting from sales promotion techniques such as price discounts, coupons, free samples, and extra product promotion, which stimulate and create a positive response from consumers to make a purchase and feel satisfied with their buying decision (Osman, Fah, and Foon, 2011; Weng and Run, 2013). Importantly, this particular situation is related to this study's finding that sales promotion has a significant correlation in buying behaviour particularly in impulse buying among Muslim credit card holders in Malaysia. Moreover, this study result is reliable according to (Badgaiyan and Verma, 2015), as sale promotion is one of the factors that influence consumers to engage in impulsive buying, which as mentioned previously can often result in financial difficulties such as debt and regret related to the purchase. Also, it is demonstrated that sales promotional activities 
conducted by retailers will undoubtedly influence the consumer in Malaysia to buy impulsively, thereby contributing towards household debt and financial difficulties.

\section{Conclusion}

As mentioned by previous scholars, not all unplanned buying is impulsively decided, for example, a scenario where consumers buy the items that are listed in their shopping list, although, the brand of that product is decided impulsively (Rook, 1987). Furthermore, it has been demonstrated that the meaning of impulse buying behaviour is broad and vague. However, this study's concern is on impulse buying behaviour that results in adverse effects such as bankruptcy and credit card debt.

The general objective of this study is to examine the relationship between sale promotion and impulse buying behaviour. Based on the results of this study, it is reasonable to conclude that the factors sale promotion drives the consumer to engage in impulse buying behaviour. This demonstrated that Muslims currently tend to ignore religious teachings and values when engaging in matters of desire, such as impulse buying behaviour. It can be concluded that the ability and capacity to control desire is the central point of this issue. If Muslims strive to fight and avoid their unnecessary and inappropriate desires and being moderate in every aspect of their lives, then they will be able to avoid extravagance and lavish spending during promotion period which inevitably results in financial difficulties and a miserable life by experiencing debt, bankruptcy, social relationship problems, health and mental illness. Moreover, Muslim consumers should be concerned with the teachings of Islam regarding consumerism as stated by the theory of maqasid syariah which five preserving elements need to concern namely; preserving of faith, soul, wealth, mind, as well as offspring. Being moderate is the primary key in a Muslim's life. Accordingly, the main objective of this study was answered appropriately. The findings and work performed in this study will undoubtedly contribute extending the present knowledge on the study of impulse buying behaviour.

\section{Practical Implication}

From the results obtained in this study, the researcher concludes that the influence of situational variable namely, sales promotion, should be given greater attention towards educating the community from practising no beneficial consumption activities. Therefore, the relevant authorities should consider these matters as their primary concern and develop programs to educate the public to control their buying desires, particularly during sales promotion periods. Performing proper, if not appropriate campaigns or advertisements regarding the advantages and disadvantages of financial planning is crucial as poor financial management will cause detrimental effects toward the country's economy. The stability of the economy partially depends on how well the public manages their financials and liabilities.

\section{Limitation and Future Research}

The limitations of this study are beyond the researcher's ability to resolve and hence, future research is required. As this study's independent variables were rarely examined in previous studies, there was not a sufficient nor appropriate scale to measure the variables. For instance, the measurement scale for the variables of sales promotion contain out-dated or obsolete questions of measurement. This study, therefore, needed to utilise this scale measurement due to the limitation of time and the inability to design a new scale measurement. However, this study made some adjustments to the scale so that it corresponded to this study's content.

To overcome the limitation of this study, future research should test and examine a new measurement scale for sales promotion in impulse buying behaviour studies. This study 
believes that the variable of sale promotion requires new measurement scale items that can measure the correlations of sale promotion with impulse buying behaviour. Prior studies tended to employ and refer to measurement scale items from (Karbasivar and Yarahmadi, 2011; Badgaiyan and Verma, 2015; Youn and Faber, 2000) for sales promotion measurement items. These measurement scale items were established to represent general items to measure buying behaviour only, that is, they were not specific for impulse buying behaviour measurement.

\section{References}

Akram, U., Hui, P., Khan, M. K., Saduzai, S. K., Akram, Z., \& Bhati, M. H. (2017). The plight of humanity: Online impulse shopping in China. Human Systems Management, 36(1), 73-90.

Akram, U., Hui, P., Khan, M. K., Tanveer, Y., Mehmood, K., \& Ahmad, W. (2018). How website quality affects online impulse buying: moderating effects of sales promotion and credit card use. Asia Pacific Journal of Marketing and Logistics, 30(1), 235-256.

Alvarez, B. A., \& Casielles, R. V. (2005). Consumer evaluations of sales promotion: the effect on brand choice. European Journal of Marketing, 39(1/2), 54-70.

Applebaum, W. (1951). Studying Customer Behavior in Retail Stores. The Journal of Marketing, 16(2), 172-179.

Aragoncillo, L. And Orus, C. (2018), "Impulse buying behaviour: an online-offline comparative and the impact of social media", Spanish Journal of Marketing - ESIC, Vol. 22 No. 1, pp. 42-62.

Atulkar, S., \& Kesari, B. (2018). Role of consumer traits and situational factors on impulse buying: does gender matter? International Journal of Retail \& Distribution Management, 46(4), 386-405.

Badgaiyan, A. J., \& Verma, A. (2015). Does urge to buy impulsively differ from impulsive buying behaviour? Assessing the impact of situational variables. Journal of Retailing and Consumer Services, 22, 145-157.

Badgaiyan, A. J., Verma, A., \& Dixit, S. (2016). Impulsive buying tendency: Measuring important relationships with a new perspective and an indigenous scale. IIMB Management Review, 28(4), 186-199.

Badgaiyan, A. J., Dixit, S., \& Verma, A. (2017). If brands are people, then people are impulsive:assessing the connection between brand personality and impulsive buying behaviour. Journal of Brand Management, 24(6), 622-638.

Bahrainizad, M., \& Rajabi, A. (2018). Consumers' perception of usability of product packaging and impulse buying: considering consumers' mood and time pressure as moderating variable. Journal of Islamic Marketing, 9(2), 262-282.

Beatty, S. E., \& Elizabeth Ferrell, M. (1998). Impulse buying: Modeling its precursors. Journal of Retailing, 74(2), 169-191.

Bossuyt, S., Vermeir, I., Slabbinck, H., De Bock, T., \& Van Kenhove, P. (2017). The compelling urge to misbehave: Do impulse purchases instigate unethical consumer behavior? Journal of Economic Psychology, 58, 60-76.

Brici, N., Hodkinson, C., \& Mort, G. S. (2013). Young Consumers Conceptual differences between adolescent and adult impulse buyers. Young Consumers, 14(2), 258-279.

Bryman, A., \& Bell, E. (2007). Business Research Method (Second Edition). New York: Oxford University Press.

Burgess, B., Yaoyuneyong, G., \& Gibbs, S. (2014). Gender, Self-construal and Impulse Buying Behavior of Young Thai Consumers. Asian Journal of Business Research, 4(1), 1-15

Cengiz, H. (2017). Effect of the need for popularity on purchase decision involvement and impulse-buying behavior concerning fashion clothing. Journal of Global Fashion Marketing, 8(2), 113-124. 
Chang, H. J., Yan, R.-N., \& Eckman, M. (2014). Moderating effects of situational characteristics on impulse buying. International Journal of Retail \& Distribution Management, 42(4), 298-314.

Chen, S.F. S., Monroe, K. B., \& Lou, Y. C. (1998). The effects of framing price promotion messages on consumers' perceptions and purchase intentions. Journal of Retailing, 74(3), 353-372.

Chen, S.F. S., Monroe, K. B., \& Lou, Y. C. (1998). The effects of framing price promotion messages on consumers' perceptions and purchase intentions. Journal of Retailing, 74(3), 353-372.

Chen, Y. F., \& Wang, R. Y. (2015). Are human rational? Exploring factors influencing impulse buying intention and continuous buying intention. Journal of Consumer Behaviour, 15, 186-197.

Chin, W. W., Gopal, A., Salisbury, W. D., \& David, W. (1997). Faithfulness of Appropriation Advancing Structuration: to Measure the The of Adaptive of a Scale Development Theory of Appropriation. Information Systems Research, 8(4), 342-367.

Chuang, C.-L., Tian, H.-L., \& Lin, R.-H. (2015). Integrating Certainty Effect and Noninteractive Social Influence Into Impulse Buying. Social Behavior and Personality: An International Journal, 43(5), 777-793.

Clover, V. T. (1950). Relative Importance of Impulse Buying in Retail Stores. Journal of Marketing, 15(1), 66-70.

Cohen, J. (1977). Statistical Power Analysis for the Behavioral Sciences. (Revised Edition, Vol. 73). USA: Academic Press, Inc.

Cohen, J., Cohen, P., West, S. G., \& Aiken, L. (2003). Applied Multiple Regression / Correlation Analysis for the Behavioral Sciences (Third Edition). London: Lawrence Erlbaum Associates Publishers.

Cotton, B. C., \& Babb, E. M. (1978). Response to Promotional Deals. Journal of Marketing, 42(3), 109-113.

Dhaundiyal, M., \& Coughlan, J. (2016). Investigating the effects of shyness and socialibility on consumer impulse buying tendencies: The moderating effect of age and gender. International Journal of Retail, 44(9), 923-939.

Falahat, M., Migin, M. W., Chuan, C. S., \& Kai, S. B. (2017). Determinants of consumer impulse buying behaviour in context of footwear industry. Advanced Science Letters, 23(4), 3068-3070.

Floh, A., \& Madlberger, M. (2013). The role of atmospheric cues in online impulse-buying behavior. Electronic Commerce Research and Applications, 12(6), 425-439.

Gong, Y., Hou, W., Zhang, Q., \& Tian, S. (2018). Discounts or gifts? Not just to save money. Journal of Contemporary Marketing Science, 1-24.

Gong, Y., Hou, W., Zhang, Q., \& Tian, S. (2018). Discounts or gifts? Not just to save money. Journal of Contemporary Marketing Science, 1-24.

Hair, J. F., Black, W. C., Babin, B. J., \& Anderson, R. E. (2014). Multivariate Data Analysis (Seventh Edition). USA: Pearson.

Hair, J. F., Hult, G. T. M., Ringle, C. M., \& Sarstedt, M. (2014). Partial least squares structural equation modeling (PLS-SEM). USA: SAGE Publication.

Hair, J. F., Ringle, C. M., \& Sarstedt, M. (2011). PLS-SEM: Indeed a Silver Bullet. The Journal of Marketing Theory and Practice, 19(2), 139-152.

Hair, J. F., Ringle, C. M., \& Sarstedt, M. (2011). The Use of Partial Least Squares (PLS) to Address Marketing Management Topics: From the Special Issue Guest Editors . Journal of Marketing Theory and Practice, 18(2), 135-138. 
Hair, J. F., Sarstedt, M., Ringle, C. M., \& Mena, J. A. (2012). An assessment of the use of partial least squares structural equation modeling in marketing research. Journal of the Academy of Marketing Science, 40(3), 414-433.

Hair, J., Hult, G. T. M., Ringle, C. M., \& Sarstedt, M. (2017). A Primer On Partial Least Squares Structural Equation Modeling (PLS-SEM) (Second Edition). USA: SAGE Publication,Inc.

Hardesty, D. M., \& Bearden, W. O. (2003). Consumer evaluations of different promotion types and price presentations: the moderating role of promotional benefit level. Journal of Retailing, 79(1), 17-25.

Hardesty, D. M., \& Bearden, W. O. (2003). Consumer evaluations of different promotion types and price presentations: the moderating role of promotional benefit level. Journal of Retailing, 79(1), 17-25.

Huang, L. T. (2016). Flow and social capital theory in online impulse buying. Journal of Business Research, 69(6), 2277-2283.

Hulland, J. (1999). Use of Partial Least Squares ( Pls ) in Strategic Management Research : a Review of Four Recent Studies. Strategic Management Journal, 204(November 1996), 195-204

Hulten, P., \& Vanyushyn, V. (2011). Impulse purchases of groceries in France and Sweden. Journal of Consumer Marketing, 28(5), 376-384.

Hulten, P., \& Vanyushyn, V. (2014). Promotion and shoppers' impulse purchases: the example of clothes. Journal of Consumer Marketing, 31(2), 94-102.

Jabatan Insolvensi Malaysia. (2017). Laporan Tahunan Bahagian Hal Ehwal Undang-Undang. Kuala Lumpur, Malaysia.

Kacen, J. J., Hess, J. D., \& Walker, D. (2012). Spontaneous selection: The influence of product and retailing factors on consumer impulse purchases. Journal of Retailing and Consumer Services, 19(6), 578-588.

Karbasivar, A., \& Yarahmadi, H. (2011). Evaluating Effective Factors on Consumer Impulse Buying Behavior. Asian Journal of Business Management Studies, 2(4), 174-181.

Khan, N., Hui Hui, L., Booi Chen, T., \& Yong Hoe, H. (2015). Impulse Buying Behaviour of Generation Y in Fashion Retail. International Journal of Business and Management, 11(1), 144-151

Kollat, D. T., \& Willett, R. P. (1969). Is Impulse Purchasing Really a Useful Concept for Marketing Decisions? Journal of Marketing, 33(1), 79-83.

Lammers, H. B. (1991). The effect of free samples on immediate consumer purchase. Journal of Consumer Marketing, 8(2), 31-37.

Leong, L. Y., Jaafar, N. I., \& Sulaiman, A. (2017). Understanding impulse purchase in Facebook commerce: does Big Five matter? Internet Research, 27(4), 786-818.

Liao, S.-L., Shen, Y.-C., \& Chu, C.-H. (2009). The effects of sales promotion strategy, product appeal and consumer traits on reminder impulse buying behaviour. International Journal of Consumer Studies, 33(3), 274-284.

Liao, S.-L., Shen, Y.-C., \& Chu, C.-H. (2009). The effects of sales promotion strategy, product appeal and consumer traits on reminder impulse buying behaviour. International Journal of Consumer Studies, 33(3), 274-284.

Lichtenstein, D. R., Ridgway, N. M., \& Netemeyer, R. G. (1993). Price Perceptions and Consumer Shopping Behavior: A Field Study. Journal of Marketing Research, 30(2), 234-245.

Lichtenstein, D. R., Ridgway, N. M., \& Netemeyer, R. G. (1993). Price Perceptions and Consumer Shopping Behavior: A Field Study. Journal of Marketing Research, 30(2), 234-245 
Liu, Y., Li, H., \& Hu, F. (2013). Website attributes in urging online impulse purchase: An empirical investigation on consumer perceptions. Decision Support Systems, 55(3), 829-837.

Lo, L. Y. S., Lin, S. W., \& Hsu, L. Y. (2016). Motivation for online impulse buying: A twofactor theory perspective. International Journal of Information Management, 36(5), 759-772.

Lucas, M., \& Koff, E. (2017). Body image, impulse buying, and the mediating role of negative affect. Personality and Individual Differences, 105, 330-334.

Luo, X. (2005). How Does Shopping With Others Influence Impulsive Purchasing? Journal of Consumer Psychology, 15(4), 288-294.

Martinez, E., \& Montaner, T. (2006). The effect of consumer's psychographic variables upon deal-proneness. Journal of Retailing and Consumer Services, 13, 157-168

Martinez, E., \& Montaner, T. (2006). The effect of consumer's psychographic variables upon deal-proneness. Journal of Retailing and Consumer Services, 13, 157-168.

Mohan, G., Sivakumaran, B., \& Sharma, P. (2013). Impact of store environment on impulse buying behavior. European Journal of Marketing, 47(10), 1711-1732.

Mokhlis, S. (2009b). Relevancy and Measurement of Religiosity in Consumer Behavior Research. International Business Research, 2, 75-84.

Muratore, I. (2016). Teen's impulsive buyers: what is the role of price. International Journal of Retail \& Distribution Management, 44(11), 1166-1180.

Neslin, S. A., Henderson, C., \& Quelch, J. (1985). Consumer Promotions and the Acceleration of Product Purchases. Marketing Science, 4(2), 147-165.

Osman, S., Fah, B. C. Y., \& Foon, Y. S. (2011). Simulation of Sales Promotions towards Buying Behavior among University Students. International Journal of Marketing Studies, 3(3), 78-88.

Ozen, H., \& Engizek, N. (2014). Shopping online without thinking: being emotional or rational? Journal of Marketing and Logistics, 26(1).

Ozer, L., \& Gultekin, B. (2015). Pre- and post-purchase stage in impulse buying: The role of mood and satisfaction. Journal of Retailing and Consumer Services, 22, 71-76.

Peattie, K., \& Peattie, S. (1995). Sales promotion - a missed opportunity for services marketers? Journal of Service Industry Management, 6(1), 22-39.

Pelet, J., Lecat, B., Khan, J., Rundle-Thiele, S., Lee, L., Ellis, D., Wolf, M., Kavoura, A., Katsoni, V. and Wegmann, A. (2018), "Winery website loyalty: the role of sales promotion and service attributes", International Journal of Wine Business Research, Vol. 30 No. 2, pp. 138-152.

Pornpitakpan, C., Yuan, Y., \& Han, J. H. (2016). The effect of salespersons' retail service quality and consumers' mood on impulse buying. Australasian Marketing Journal, 25(1), 2-11.

Prashar, S., Parsad, C., \& Vijay, T. S. (2016). Segmenting Young Indian Impulsive Shoppers. Journal of International Consumer Marketing, 29(1), 35-47.

Rook, D. W. (1987). The Buying Impulse. Journal of Consumer Research, 14(2), 189-199.

Rook, D. W., \& Fisher, R. J. (1995). Normative Behavior Influences on Impulsive Buying Trait Aspects of Buying Impulsiveness. Journal of Consumer Research, 22(3), 305-313.

Rowley, J. (2014). Designing and using research questionnaires. Management Research Review, 37(3), 308-330.

Seinauskiene, B., Mascinskiene, J., \& Jucaityte, I. (2015). The Relationship of Happiness, Impulse Buying and Brand Loyalty. Procedia - Social and Behavioral Sciences, 213, 687-693.

Sharma, P., Sivakumaran, B., \& Marshall, R. (2010b). Impulse buying and variety seeking: A trait-correlates perspective. Journal of Business Research, 63(3), 276-283. 
Sofi, S. A., \& Nika, F. A. (2017). Role of intrinsic factors in impulsive buying decision: An empirical study of young consumers. Arab Economic and Business Journal, 12(1), 2943.

Stern, H. (1962). The Signficance of Buying Impulse Today. Journal of Maketing, 26(2), 5962

Stone, M. A., \& Desmond, J. (2007). Fundamentals of Marketing. USA: Routledge.

Sultan, A. J., Joireman, J., \& Sprott, D. E. (2012). Building consumer self-control: The effect of self-control exercises on impulse buying urges. Marketing Letters, 23(1), 61-72.

Tendai, M., \& Crispen, C. (2009). In-store shopping environment and impulsive buying. African Journal of Marketing Management, 1(4), 102-108.

The Nielsen Global Retail Format Preferences Survey. (2015). More Than Half of Global Consumers are Willing to but Groceries Online. Retrieved Oktober 102016 from http://www.nielsen.com/hu/hu/press-room/2015/more-than-half-of-global-consumersare-willing-to-buy-groceries-online.html

The Nielsen Global Survey of E-commerce. (2014). Malaysians Rank Among the World's Most Avid Online Shoppers. Retrieved December 2017 from http://www.nielsen.com/my/en/press-room/2014/e-commerce.html

Tinne, W. (2011). Factors Affecting Impulse Buying Behavior of Consumers at Superstores in Bangladesh. ASA University Review, 5(1), 209-220.

Tjiptodjojo, K. I., \& Setyawan, S. (2016). Free product samples and its impact on impulse buying. International Journal of Applied Business and Economic Research, 14(14), 477-483.

Turkyilmaz, C. A., Erdem, S., \& Uslu, A. (2015). The Effects of Personality Traits and Website Quality on Online Impulse Buying. Procedia - Social and Behavioral Sciences, 175, 98-105.

Verhagen, T., \& Van Dolen, W. (2011). The influence of online store beliefs on consumer online impulse buying: A model and empirical application. Information and Management, 48(8), 320-327.

Weng, J. T., \& Run, E. C. De. (2013). Consumers' personal values and sales promotion preferences effect on behavioural intention and purchase satisfaction for consumer product. Asia Pacific Journal of Marketing and Logistics, 25(1), 70-101.

Weng, J. T., \& Run, E. C. De. (2013). Consumers' personal values and sales promotion preferences effect on behavioural intention and purchase satisfaction for consumer product. Asia Pacific Journal of Marketing and Logistics, 25(1), 70-101.

West, C. J. (1951). Result of Two Years of Study Into Impulse Buying. The Journal of Marketing, 362-364.

Wu, P.T., \& Lee, C.J. (2015). Impulse buying behaviour in cosmetics marketing activities. Total Quality Management \& Business Excellence, (July), 1-21.

Xu, Y., \& Huang, J. S. (2014). Effects of Price Discounts and Bonus Packs on Online Impulse Buying. Social Behavior and Personality, 42(8), 1293-1302

Xu, Y., \& Huang, J. S. (2014). Effects of Price Discounts and Bonus Packs on Online Impulse Buying. Social Behavior and Personality, 42(8), 1293-1302

Youn, S., \& Faber, R. J. (2000). Impulse buying: Its relation to personality traits and cues. Advances in Consumer Research, 27(1), 179-185.

Youn, S., \& Faber, R. J. (2000). Impulse buying: Its relation to personality traits and cues. Advances in Consumer Research, 27(1), 179-185

Zhuang, G., Tsang, A. S. ., Zhou, N., Li, F., \& Nicholls, J. A. F. (2006). Impacts of situational variables on buying decisions in shopping malls: An empirical study with multinational data. European Journal of Marketing, 40(1/2), 17-43. 